\title{
INNOVÁCIÓS POTENCIÁL FELMÉRÉS TANULSÁGAI EGY ELMARADOTT RÉGIÓBAN
}

\author{
(Results of an Innovation Potential Analysis \\ in a Backward Region) \\ MÁRTON GYÖRGY
}

Kulcsszavak:

innováció kis-és középvállalkozások Dél-dunántúli régió innováció-finanszirozás

Az. Európai Unióban elfogadott értelmezés alapján az innovációs képesség döntöen befolyásolja a vállalkozások versenyképességét, sikerességét. A tanulmány kisérletet tesz arra, hogy igazolja, az innovíció egy elmaradott, jelentös hátrányokkal kïszködö magyarországi régió esetében is hajtóerejét képezheti a gazdaság versenyképes müködésének. A hazai kis-és középvállalkozások innovativitását számos tényezö befolyásolja, melyek között megtaláljuk a vállalkozások alapjellemzöit ugyanúgy, mint a vállalkozások humán kapacitásának színvonalát. Az innovációs folyamatok elömozdítása érdekében regionális szinten nagy szerepe van egy hatékony innováció-finanszírozási rendszer, valamint egy koherens innovációs intézményrendszer kialakításának.

\section{Az új innovációs paradigma jellemzői}

Az innováció már hosszú ideje alapvető szerepet játszik a gazdaság fejlödésében. $\mathrm{Az}$ innovációs fejlesztések hozzájárulnak a vállalkozások termelékenységének növeléséhez, ezáltal kulcsszerepet töltenek be azok versenyképességének javításában, ami a gazdasági növekedés egyik kulcseleme.

A hagyományos, indusztriális korszakra jellemző felfogás szerint az innovációs folyamat egy zárt, lineáris modellként értelmezendö: az innováció alapvetöen a kutatási-fejlesztési tevékenységekre $(\mathrm{K}+\mathrm{F})$ szúkíthető le, és meghatározó jelleggel a kutatóhelyek és nagyvállalatok köré összpontosul. Az államilag finanszírozott alapkutatások legfỏbb hasznosítói a nagyvállalatok, amelyek $\mathrm{K}+\mathrm{F}$ részlegei felelősek az alkalmazott kutatási tevékenységek elvégzéséért, tehát a kutatási eredmények gazdasági hasznosításáért. Az egész innovációs folyamatot a nagyfokú hierarchia és termelésközpontúság jellemzi, a rendszer rugalmassága rendkívül alacsony.

Az innováció értelmezésében a nyolcvanas évek végén és a kilencvenes évek elején paradigmaváltás következett be. A posztindusztriális korszakra történő áttérés alapvetően átértékelte a gazdasági versenyképesség alapfeltételeinek a súlyát, a gazdasági fejlődés új hajtóerői kerültek a figyelem középpontjába. A nagyvállalatok eddigi domináns szerepe meggyengült, felértékelődtek a dinamikus kis-és középvállalkozások (KKV-k), valamint a vállalkozások közötti hálózatszerű együttmúködések. Ebben az új rendszerben átértékelödött az innováció fogalma és gazdaságban betöltött szerepe is. A korábbi lineáris, termelésközpontú modell helyébe a többpólusú, elosztás-orientált innovációs modell lépett. Az új modell a fogyasztók 
igényeinek megfelelő innovációkra koncentrál, törekszik az innovációs folyamatok decentralizációjára. Az innováció fogalmát kiterjeszti az innovációs lánc egészére, és hangsúlyozza a lánc valamennyi pólusának (alapkutatás, alkalmazott kutatás, termékfejlesztés, technológia-fejlesztés, üzleti szolgáltatások, értékesítés, marketing) egyenrangú szerepét és a köztük lévő hálózatszerủ kapcsolatok jelentőségét. Szakít az innovációs folyamat hierarchikus jellegével, és nagy jelentỏséget tulajdonít a $K K V$-k intenzív szerepvállalásának az innovációs folyamatban. Végül az új modell jellegéből fakadóan felértékelődik az innovációs transzfer szervezetek szerepe, valamint előtérbe kerül az innovációs tevékenységek decentralizált jellege, az új modell az eredményes innovációs tevékenységek egyik fontos tényezőjének tekinti a regionális alapú innovációs fejlesztések súlyának növelését (Raffay-Gál 1999).

Az új innovációs modell jellemzöi közül két alapvető fontosságú tényezőre külön érdemes felhívni a figyelmet:

- az innovációs aktivitás erősítése a sikeres regionális fejlesztési stratégiák egyik alapelemévé válik;

- a KKV-k egyre meghatározóbb szerepet töltenek be az innovációs folyamatokban.

A posztindusztriális korszakban a régiók számára kínálkozó két fö fejlödési pálya a következő lehet:

- adaptív fejlesztési stratégia, ami a meglévő és bevált fejlesztési stratégiák átvêtelén és a helyi viszonyokra történő adaptálásán alapul;

- innovativ fejlesztési stratégia, ami célul tüzi ki a meglévő regionális termékszerkezet és piaci kapcsolatrendszer megújítását, a fejlődés mozgatórugójának új piacok meghódítását, valamint új termékek és technológiák kifejlesztését tekinti.

Az Európai Bizottság jelentésében (Green Paper on Innovation 1995) megerösíti az innovációs politika jelentőségét a területfejlesztésben. Kiemeli, hogy az innovációnak különös fontosságot kell tulajdonítani az elmaradott térségekben, olyan eszköznek kell tekinteni, amelynek segítségével a fejletlen régiók gyorsan felzárkózhatnak a kiemelkedö régiókhoz. A tanulmány hangsúlyozza továbbá a helyi viszonyoknak és adottságoknak megfelelő innovációs tevékenységek erősítését és a vállalkozások együttmúkődésén alapuló, innovatív fejlesztések fontosságát, amit a KKV-k versenyképességét meghatározó egyik legfontosabb tényezőnek kell tekinteni.

Az Európai Unió jövőbeni kohéziós politikájának alapelveit lefektető harmadik kohéziós jelentés (A new partnership... 2004) az elmaradott régiók fejlesztésére irányuló, ún. konvergencia célkitüzés esetében a kohéziós politika számára kettős célt határoz meg: a versenyképesség és a foglal koztatottság növelését. A regionális versenyképesség, azaz a régiók sikeressége az Európai Unióban jelenleg elfogadott értelmezésnek megfelelően a magas egy lakosra jutó jövedelemszinttel mérhető. A régiók sikeressége, azaz a lakossági jövedelemszint mértéke pedig négy alaptényezőre vezethető vissza, melyek között kitüntetett szerepet tölt be az innovációs tevékenységek kiterjedtsége (Farkas-Lengyel 200I). 
Márton György : Innovációs potenciál felmérés tanulságai egy elmaradott régióban.

Tér és Társadalom 18. évf. 2004/3. 127-149. p.

TÉT XVIII. évf. 2004 - 3

Versenyképesség

129

\section{A $K+F$ helyzete a Dél-Dunántúlon}

A rendszerváltást követően $a K+F$ tevékenység Magyarországon nagymértékben összeszükült. A visszaesést leginkább a $\mathrm{K}+\mathrm{F}$ ráfordítások GDP-hez mért aránya mutatja: míg 1990-ben ez 1,6\% volt, addig a kilencvenes évek végére ez az arány alig több mint fél százalékra zsugorodott. Bár az ezredfordulót követően némi emelkedés tapasztalható, de az arány 2002-ben is $1 \%$ alatt maradt $(0,98 \%)$. Ugyanez a visszaesés figyelhető meg a K+F-ben foglalkoztatottak számában is: az 1990-es 59723 fö 2002-re 48727 före olvadt (Területi Statisztikai Évkönyvek). A K+F aktivitás csökkenését egyszerre magyarázza a $\mathrm{K}+\mathrm{F}$ szempontjából korábban meghatározó nagyvállalatok szétesése, a vállalkozások és a $\mathrm{K}+\mathrm{F}$ tevékenységet folytató egyetemi és kutatóintézeti szféra finanszírozási helyzetének romlása, valamint a hazai $\mathrm{K}+\mathrm{F}$ intézményrendszer rugalmatlan hozzáállása a $\mathrm{K}+\mathrm{F}$ tevékenységekkel szemben megfogalmazódó újszerủ elvárásokhoz.

A $\mathrm{K}+\mathrm{F}$ tevékenység területén a visszaesés ellenére továbbra is megmaradt - söt, némileg még erösödött is - a közösségi szféra dominanciája, Magyarországon jelenleg ez eléri a 60\%-ot; ezzel szemben az EU-országokban ez az arány 35\% (European Innovation... 2003). A $\mathrm{K}+\mathrm{F}$ erős fövárosi koncentrációja lényegében nem mérséklödött, a $\mathrm{K}+\mathrm{F}$ ráfordítások több mint kétharmada továbbra is Budapesten realizálódik.

A Dél-Dunántúl gazdasági fejlődésének hajtóerejét a szocialista iparosítás, elsősorban a nehézipar fejlesztése jelentette. A gazdaság alappilléreit túlnyomó részt a budapesti nagyvállalatok leányvállalatai jelentették, melyekben a hierarchikus vállalatszervezésnek köszönhetően az alacsony szaktudást igénylő termelési folyamatok és az életciklusuk végső fázisában lévő termékek tömegtermelése volt meghatározó. A nagyvállalatok csak részlegesen integrálódtak a helyi gazdaságba, az egyes helyi vállalati részlegek közötti együttműködések rendkívül gyengék voltak. A rendszerváltást követỏen a gazdasági recesszió első áldozatai éppen a budapesti nagyvállalatoknak a régióban jelentős súlyt képviselő leányvállalatai lettek, melyek közül sokan bezárták kapuikat, illetve többüknél jelentős létszámleépítésekre került sor.

A Dél-dunántúli régió jelenleg rendkívül gyenge innovációs potenciállal rendelkezik: 2002-es adatok alapján a $\mathrm{K}+\mathrm{F}$ ráfordítások GDP-hez mért aránya mindössze $0,51 \%$, a ráfordítások értéke a teljes magyarországi ráfordítások mindössze 3,7\%-át teszi ki. Döbbenetesen alacsony a szabadalmi bejelentések száma, 2002-ben mindössze $6 \mathrm{db}$ regisztrált bejelentés történt (országosan $217 \mathrm{db}$ ). Az innovációs képesség szempontjából pozitívumként említhetö, hogy a Közép-magyarországi régió után a Dél-Dunántúlon a legmagasabb az egyetemi hallgatók 1000 lakosra jutó aránya (2002-ben 33,2 fö). Ennek ellenére a régió részesedése az országban dolgozó kutatók és fejlesztők számából meglehetősen alacsony, 2002-ben mindössze 4\% (Területi Statisztikai Évkönyvek).

A Dél-dunántúli régió számára a jelenlegi nehéz gazdasági helyzetből történő kilábalás záloga a mára elavult gazdasági szerkezet átalakítása, a magasabb technológiai 
színvonalú termelés előtérbe helyezése lehet, melyben kulcsszerepet játszik a termék- és termelési innovációk hátterének megteremtése (Horváth 1998).

\section{Az innovációs felmérés körébe bevont vállalkozások alapjellemzöi}

A Dél-dunántúli régióban 2002 elején egy nagyszabású regionális innovációs potenciál felmérés került lebonyolításra. ' A felmérés célja a régió kis- és középvállalkozásai innovációs aktivitásának, szolgáltatási és finanszírozási igényeinek felmérése, valamint ennek alapján ajánlások megfogalmazása volt az innovációs tevékenységek erösítése érdekében.

A felmérés alapját egy 60 kérdésböl álló innovációs és technológiai transzfer kérdöív jelentette. A kérdőív szerkezetét tekintve három fö részre tagolódott:

- a vállalkozás alapadatai: a vállalkozás alapjellemzöi, müködési köre, teljesítménymutatóinak alakulása, várakozásai;

- az innovációs tevékenység jellemzői: a vállalkozás által végzett innovatív tevékenység jellege, az innovatív tevékenység pénzügyi mutatói, az innováció akadályozó tényezöi, az innovációs tevékenység partnerei, az innovációval összefüggő szolgáltatások iránti igények;

- a vállalkozás finanszírozása: a vállalkozás által felvett hitelek és vissza nem térítendő támogatások jellemzői, a külső finanszírozással szemben felmerülö problémák, hitelgarancia és kockázati töke bevonásának lehetöségei.

A felmérés célcsoportját a Dél-dunántúli régió 3 megyéjében (Baranya, Somogy, Tolna) múködő vállalkozások jelentették. A felmérés személyes lekérdezési módszerrel zajlott, melynek során a kérdöívet összesen 258 , a régióban müködö vállalkozás képviselöje töltötte ki. A felmérés regionális jellegét mutatja, hogy a vizsgálatba bevont vállalkozások székhelyüket tekintve kiegyensúlyozott megyei eloszlást mutattak. Annak érdekében, hogy a lekérdezések azonos elvek szerint és megfeleló szakmai háttértámogatással bonyolódjanak le, a projekt koordinátorai az interjúk elvégzéséhez a KSH megyei igazgatóságai által kiajánlott hivatásos kérdezőbiztosok segítségét vették igénybe, akik mind a három érintett megyében a lekérdezéseket megelőzően részletes írásbeli és szóbeli tájékoztatásban részesültek a felmérés célját és az egyes kérdések jelentéstartalmát illetően.

A felmérésbe bevonásra kerülő vállalkozások leválogatása a KSH Gazdasági Szervezetek Regisztere adatbázisának felhasználásával, vállalkozásméret és tevékenységi kör alapján történt. Tekintettel arra, hogy a projekt fö célja a régióban múködő kis- és középvállalkozások innováció alapú fejlödési lehetőségeinek vizsgálata volt, a vizsgálat célcsoportját szinte kizárólagosan KKV-k képezték. A méretkategóriákat tekintve a legnagyobb számban $(63,6 \%)$ a kisvállalkozások (10-49 fö alkalmazotti létszám) képviseltették magukat. 
Márton György : Innovációs potenciál felmérés tanulságai egy elmaradott régióban.

Tér és Társadalom 18. évf. 2004/3. 127-149. p.

TÉT XVIII. évf. 2004

3

Versenyképesség

Az ágazati osztályok és gazdasági tevékenységcsoportok kivảlasztásakor a szakértők két fö szempontot vettek alapul:

- a tevékenységek illeszkedjenek a Dél-Dunántúl jelenlegi gazdasági szerkezetéhez, a kiválasztásra kerülő ágazatok adatbázison belüli súlya tükrözze a bruttó hozzáadott érték és a foglal koztatottság ágazatok közötti megoszlását;

- a kiválasztásra kerülő ágazatok között egyaránt szerepeljenek alacsony és magas átlagos technológiai színvonalú tevékenységi formák.

Ennek megfelelöen a felmérés alapját összesen 8 ipari és építőipari ágazat képezte, ezek közül is föként a feldolgozó-ipari, ezen belül is legnagyobb számban az élelmiszer-ipari, fémfeldolgozási és gépgyártási tevékenységekkel foglalkozó vállalkozások, de a mintában nagy súllyal szerepeltek az építöipari KKV-k is (1.ábra).

1. ÁBRA

A vállalkozások ágazati megoszlása

(Breakdown of SMEs by Sectors)

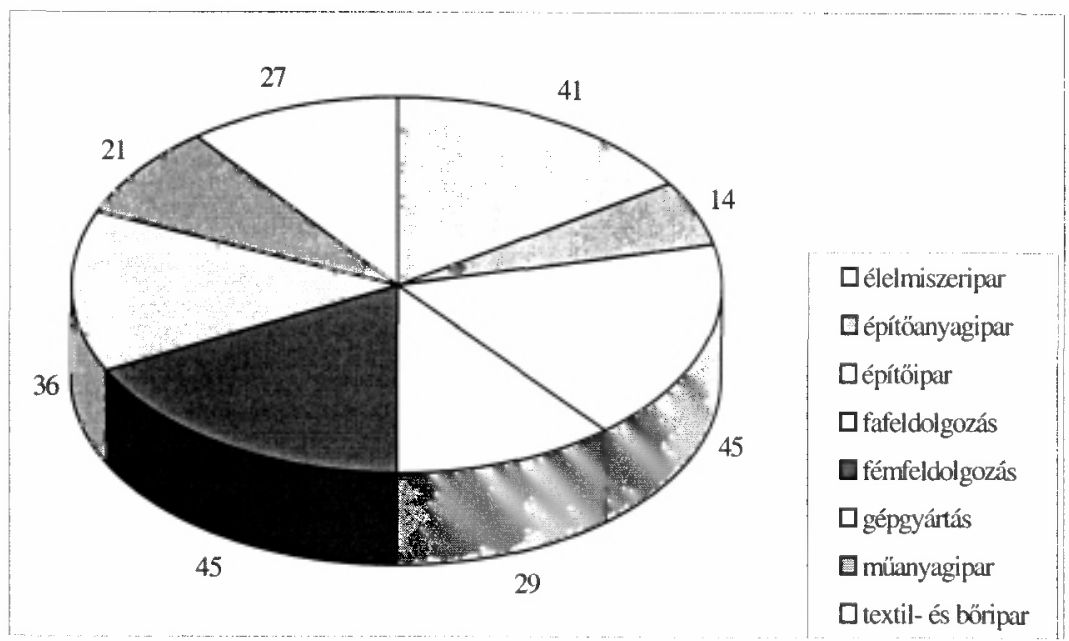

Forrás: Kérdőivek 2002.

A felmérés a magyarországi tulajdonosi háttérrel rendelkező KKV-k innovációs potenciáljának vizsgálatára fókuszált, ezért a vállalkozások túlnyomó többségét (87\%-át) a többségében hazai tulajdonú $K K V$ - $k$ alkották, ezen belül is föként ( $81 \%$ ) a tisztán hazai tulajdonosi hátterủ vállalkozások. Az adatbázisba ugyanakkor bekerültek külföldi tulajdonú $\mathrm{KKV}-\mathrm{k}$ is, ami alkalmat adott a tulajdonosi szerkezet innovációs potenciálra gyakorolt hatásainak vizsgálatára. 
Márton György : Innovációs potenciál felmérés tanulságai egy elmaradott régióban.

Tér és Társadalom 18. évf. 2004/3. 127-149. p.

132 Versenyképesség

TÉT XVIII. évf. 2004 - 3

\section{Az innováció alaptípusai és gazdasági jelentösége}

A felmérésbe bevont vállalkozások innovatív jellegének meghatározásához az a kérdés adott támpontot, ami arra irányult, hogy az elmúlt három évben a vállalkozás bevezetett-e

- az országban újnak minősülő terméket/szolgáltatást;

- a vállalkozás számára új terméket/szolgáltatást;

- új technológiát/termelési eljárást.

Az innováció fogalmát az elemzök annak tág értelmében vizsgálták. Ennek megfelelően nemcsak a kiemelkedően magas technológiai színvonalú (hi-tech) termékek előállítása vagy termelési eljárások alkalmazása került figyelembe vételre, hanem mindazon újszerünek minősíthető, a vállalkozás müködése, jövőbeni fejlődése szempontjából előremutató termék- vagy technológiai fejlesztések, amelyek növelhetik a vállalkozás versenyképességét. E tágabb értelmezést az indokolta, hogy a vizsgálat a „tradicionális" ipari és építőipari ágazatokban múködő KKV-kra koncentrált, melyek számára nem a nagy költségigényü $K+F$ fejlesztés és a hi-tech beruházások jelentik a reális elörelépést (ez irreális elvárás lenne esetükben), hanem a méretuikkel és gazdasági súlyukkal adekvát innovatív fejlesztések.

A mely $\mathrm{KKV}-\mathrm{k}$ a fenti három kérdés valamelyikére igennel válaszoltak, a vizsgálat szempontjából innovatívnak minósülttek. E tág értelmezésnek megfelelöen a $K K V-k$ mintegy 46\%-a számolt be az elmúlt 3 évben valamilyen innovációs tevékenységröl (2. ábra).

\section{2. ÁBRA}

A vállalkozások innovativitása

(Innovativity of SMEs)

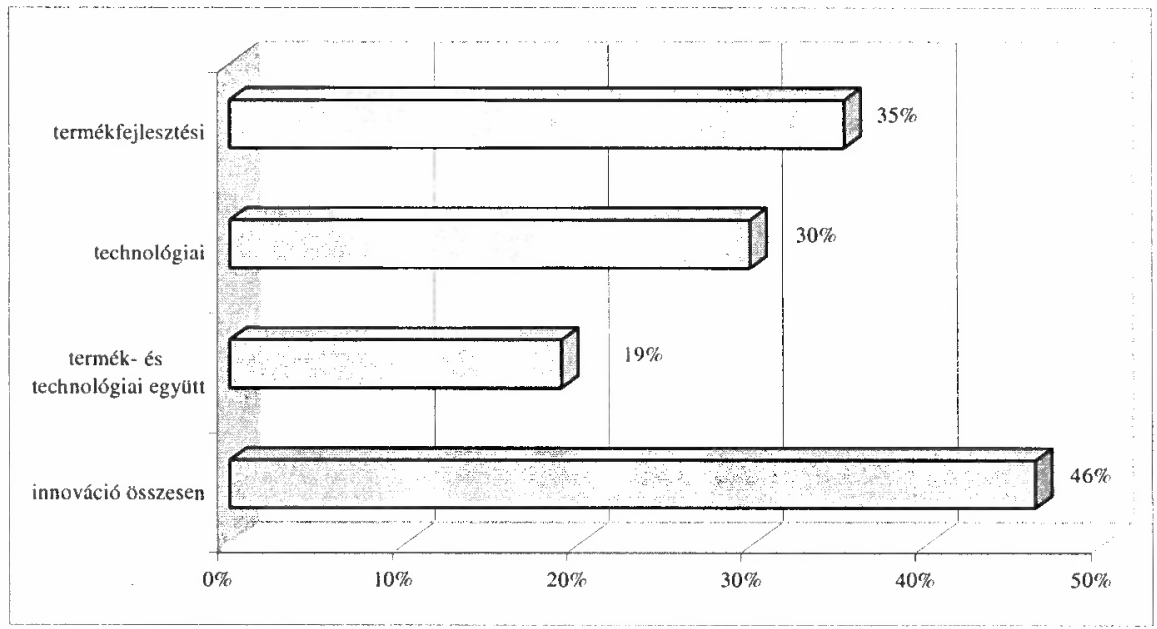

Forrás: Kérdőívek 2002. 
Az ábrán látható, hogy a termék- és szolgáltatás-fejlesztési, valamint a technológiai jellegú innováció aránya megközelítóleg hasonló, és a vállalkozások egyötödénél e két típusú innovációs tevékenység egyszerre jelentkezik.

Az innovációs tevékenységek kis- és középvállalkozások gazdasági versenyképességét erősítő hatását bizonyítja az, hogy az elmúlt három évben innovativ fejlesztést végrehajtó $K K V$-kat az átlagosnál kedvezỏbb gazdasági eredményességi mutatók jellemzik. Az innovatív KKV-k nyereségessége (árbevétel-arányos nyereség) 93\%-kal, hatékonysága (saját tőke-arányos árbevétel) pedig 31\%-kal haladja meg az átlagos szintet. Az innovációs aktivitás tehát pozitívan hat a KKV-k gazdasági teljesítményére, ami alátámasztja azt a tézist, hogy az innovatív tevékenységek ösztönzése és támogatása egyértelmủen hozzájárulhat a Dél-Dunántúl gazdasági fejlödése szempontjából meghatározó jelentőségü KKV szektor jövőbeni fejlỏdéséhez.

Az innovációs fejlesztésekből származó bevételek átlagos aránya 24,4\%-ot képvisel a vállalkozások összes árbevételéböl. Érdemes összehasonlítani ezt az értéket a Közép-Dunántúlon 1999 decemberében megvalósított innovációs felmérés eredményeivel, ahol erre a mutatóra 28,2\% adódott (Döry 2000). A dél-dunántúli arány tehát valamelyest elmarad a Közép-dunántúli régió vállalkozásainak értékétöl, azonban ez a különbség nem számottevö. Ez alátámasztja azt, hogy az innovációs fejlesztések a fejletlenebb régiókban is képesek hozzájárulni a vállalkozások bevételeinek növekedéséhez, azok fejlödéséhez.

\section{A vállalkozások innovativitását befolyásoló, azzal összefüggö tényezők}

A $K K V$-k mérete és az innovációs aktivitás között érdekes összefüggés állapitható meg. A mikrovállalkozások relatíve alacsony innovációs képességekkel rendelkeznek, túl kicsik ahhoz, hogy elegendő humán és pénzügyi kapacitást legyenek képesek az innovatív fejlesztések szolgálatába állítani. A kisvállalkozásokat azonban közel azonos innovációs aktivitás jellemzi, mint a náluk jóval nagyobb és tökeerösebb középvállalkozásokat. Ez jelzi azt, hogy a kisvállalkozási méret már elegendő lehet ahhoz, hogy a vállalkozás érdemi innovációs fejlesztéseket valósíthasson meg, tehát ez a szféra az innovációs stratégiák egyik reális akcióterülete lehet (3. ábra).

A vállalkozások jogi formája is összhangban van az elöbbiekben elmondottakkal: míg az egyéni vállalkozások és betéti társaságok (jellemzően a mikrovállalkozások közé tartozó szervezetek) rendkívül alacsony (alig 30\%-os) innovativitási rátával jellemezhetők, addig a korlátolt felelősségü társaságok és a részvénytársaságok kỏrében már több mint 47\% az innovatív fejlesztést végrehajtó vállalkozások aránya. 
Márton György : Innovációs potenciál felmérés tanulságai egy elmaradott régióban.

Tér és Társadalom 18. évf. 2004/3. 127-149. p.

\section{3. ÁBRA}

Vállalkozásméret és innováció összefüggése

(Correlation between Size and Innovativity of SMEs)

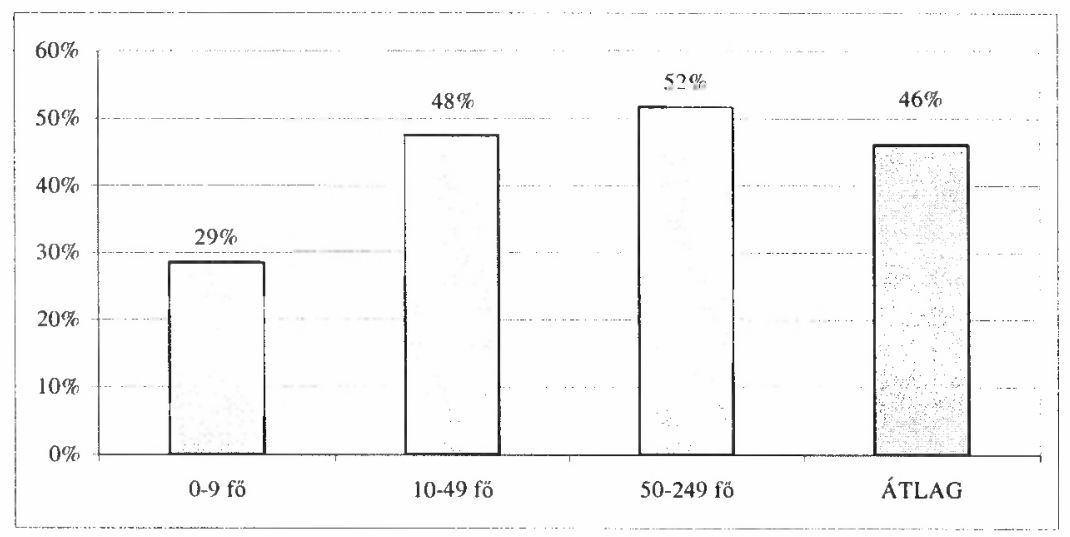

Forrás: Kérdöívek 2002.

A vállalkozások alaptevékenységét vizsgálva megállapítható, hogy a gépgyártás, a textil-és böripar, valamint az épitöanyag-ipar területén müködö $K K V$ - $k$ bizonyultak a leginnovatívabbaknak. Az említett egyes ágazatok innovativitását az alábbiak jellemzik:

- A gépgyártással foglalkozó vállalkozások esetében a termék- és a technológiai innováció egyenlő súllyal jelenik meg, valamint fontos szerepet kapnak a munkaszervezéssel kapcsolatos újítások is;

- A textil- és bóripar területén az átlagot meghaladja a termékinnováció részesedése az innovációs tevékenységekbỏl. A textiliparral foglalkozó $\mathrm{KKV}-\mathrm{k}$ esetében elsősorban új modellek és konfekciók kialakítása, míg a böripari cégeknél új börfajták alkalmazása és új terméktípusok bevezetése jellemző;

- Az építőanyag-ipart szintén átlag feletti termékinnovációs hajlandóság jellemzi. E cégekre elsösorban az új, piacképesebb építőanyag-fajták kifejlesztése a jellemző.

A felsorolt három ágazaton túl még az élelmiszer-ipari és a fafeldolgozással foglalkozó KKV-kat jellemzi átlagon felüli innovativitás:

- Az élelmiszer-ipari cégeknél elsősorban a kisebb ráfordítást és sok esetben kisebb technológiai színvonalat igénylö termékújítások jellemzőek, melyek többnyire a meglévő termékskála kibővítését, frissítését szolgálják és hozzájárulnak a termékek piacképességének javításához. Ezzel szemben az élelmiszeriparban kirivóan alacsony a technológiai fejlesztések aránya;

- A fafeldolgozással foglalkozó cégek esetében a technológia-fejlesztés az átlagosnál nagyobb arányban részesedik, ezen belül is a magas technológiai színvonalú gépek, berendezések megvásárlása, valamint az alapanyagfeldolgozáshoz és a bútorgyártáshoz kapcsolódó speciális termelési eljárások fejlesztése jellemzö (4. ábra). 
Márton György : Innovációs potenciál felmérés tanulságai egy elmaradott régióban.

Tér és Társadalom 18. évf. 2004/3. 127-149. p.

TÉT XVIII. évf. 2004 @ 3

Versenyképesség

135

\section{4. ÁBRA}

Az ágazatok innovációs potenciál-struktúrája

(Structure of Innovation Potential in Different Sectors)

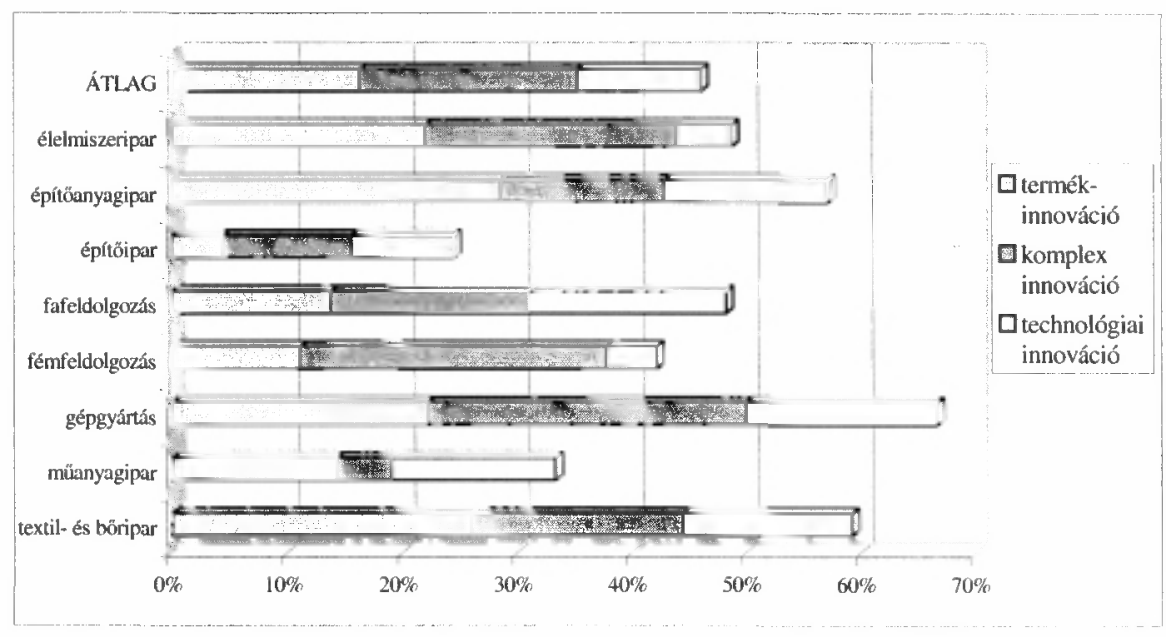

Forrás: Kérdőívek 2002.

Szembetünö az épitöiparban müködö cégek alacsony innovációs hajlandósága, ami nem éri el az átlagos innovativitási ráta felét. Az építőipari cégek által megvalósított alacsony számú innovatív fejlesztés elsősorban a termelési technológia javításához, azon belül is főleg az új, korszerủ építőipari gépek beszerzéséhez kötődik.

Az ágazati összehasonlításon túl a kérdőív rákérdezett a vállalkozások fỏ tevékenységének jellegére is. Eszerint az alábbi tevékenységi formák mutatkoznak innovatívnak:

- Az elözetes elképzelésekkel összhangban a saját késztermék elöállítással foglalkozó cégek átlagon felül innovatívaknak mutatkoznak (57\%-os innovativitási ráta).

- A beszállitói tevékenység szintén serkentóleg hat az innovációs aktivitásra. A szállítóként vagy vevőként beszállítói kapcsolatban lévő KKV-k 49\%-a mutatkozott innovatívnak, a mindkét típusú beszállítást végző, beszállítói láncban múködő vállalkozások 52\%-a számolt be innovatív tevékenységröl.

- Némileg meglepỏ módon, viszonylag kedvezö innovációs hajlandóság jellemzi azokat a $\mathrm{KKV}$-ket is, amelyek bérmunkában végzett termelést folytatnak (48\%-uk innovativ). A bérmunka tevékenységet általánosságban nem szokás az innovatív fejlődési modellre jellemzö viszonyrendszerként értelmezni, ezért is fontos megállapítás, hogy e szerződéses viszonyok a déldunántúli KKV-k fejlődése szempontjából jelentős szerepet tölthetnek be, és ezek a kapcsolatrendszerek nincsenek ellentétben az innováció-orientált fejlödési pálya feltételeivel. 
Ezzel szemben jóval az átlag alatti innovációs aktivitás jellemző a fő profilként kereskedelmi tevékenységet és üzleti, müszaki vagy építőipari szolgáltatást végző cégekre (e vállalkozásoknak kevesebb mint 30\%-a végez innovatív jellegủ tevékenységet). Mindez erősen alátámasztja az innovációs tevékenységek ipari tevékenységekhez való szoros kötödését.

A KKV-k innovációs aktivitását kedvezóen befolyásolja a külföldi tỏke jelenléte. A külföldi töke jelenléte mellett müködő vállalkozások az átlagot meghaladó mértékben mutatkoznak innovatívnak (a cégek több mint 52\%-a valósított meg a közelmúltban innovációs fejlesztést). Érdemes megjegyezni, hogy a külföldi tőke vállalkozásokon belüli mértéke már irreleváns az innovációs hajlandóság szempontjából, már a kisebbségi külföldi részesedés is jelentösebb innovációs aktivitást involválhat.

Fontos összefüggés állapítható meg a vállalkozások exportorientáltsága és az innovációs hajlandóságuk között. Egyértelmủen megállapítható, hogy az exporttevékenység inspirálja az innovációs tevékenységet: az árbevételük egy bizonyos részét külpiacokról megszerző vállalkozások innovativitása mintegy 17\%-kal haladja meg a csak hazai piacra szállító vállalkozásokét. Természetesen a korreláció ellentétes irányban is értelmezhető: az innovatív fejlesztéseket megvalósító vállalkozások sikeresebben képesek megfelelni a külföldi piacok elvárásainak.

Érdekes, hogy a külső piacokra orientált müködés és az innováció kapcsolata országon belül is megfigyelhető. Míg a dominánsan a saját településükre, illetve megyéjükbe szállító vállalkozások (árbevételük minimum 50\%-a innen származik) innovációs rátája mindössze $32 \%$, addig a Dél-dunántúli régió piacára orientált cégeket már 37\%-os, a terméküket dominánsan az ország egész területén értékesítő vállalkozásokat pedig 44\%-os innovációs ráta jellemzi.

Látható, hogy az innovativitás, mint a versenyképesség egyik alapfeltétele maga után vonja a vállalkozások exportorientált müködését. Ez a következtetés is alátámasztja a Dél-dunántúli régióra vonatkozó gazdaságfejlesztési programokban gyakran megfogalmazott tételt, miszerint a régió kis- és középvállalkozásai versenyképesebb müködésének és ezen keresztül a jövőbeni fejlődésüknek egyik kulcsfontosságú tényezője a vállalkozások export aktivitásának növekedése.

A vállalkozások innovációs hajlandósága összefüggésben van a vállalkozások humán és szervezeti müködési jellemzőivel is. A felmérés kimutatta, hogy a KKVkben foglalkoztatottak képzettsége és az alkalmazottak nyelvtudása ösztönzőleg hat az innovációs fejlesztésekre. A felsőfokú végzettségü alkalmazottakat foglalkoztató KKV-k az átlagnál 3\%-kal, az idegen nyelvtudással rendelkező alkalmazottakat foglalkoztató KKV-k az átlagnál 9\%-kal bizonyultak innovatívabbaknak. Ez is mutatja azt, hogy a KKV-k innováció-orientált fejlesztéséhez elengedhetetlenül szükséges a vállalkozások humánerőforrás-kapacitásainak fejlesztése.

A minöségbiztositási tanúsítvánnyal rendelkezö cégek is innovatívabbnak mutatkoznak az átlagosnál (5\%-kal). Megállapítható tehát, hogy a minőségbiztosítási rendszerek bevezetésének támogatása szintén fontos a KKV-k innovatív fejlödése szempontjából. 
A vállalkozások innovativitásának másik jellemző paramétere $a K+F$ ráfordítások aránya a vállalkozások árbevételében. A felmérésbe bevont KKV-kre összességében 1,65\%-os arány adódott, ami messze alatta marad a közép-dunántúli vállalkozások esetében mért 4,6\%-os árbevétel-arányos $\mathrm{K}+\mathrm{F}$ ráfordítási értéknek (Döry 2000). A különbség szembetủnő, és hủen mutatja Magyarország fejlettebb és elmaradottabb régióiban múködő vállalkozások közötti jelentös fejlettségbeli differenciákat.

Tanulságos következtetés vonható le a $\mathrm{K}+\mathrm{F}$ ráfordítás arányának és a vállalkozások méretkategóriáinak összehasonlításából. A várakozásokkal ellentétben a középvállalkozások messze az átlag alatti $K+F$ ráfordítási arányokat produkáltak $(0,56 \%)$, míg - meglepỏ módon - a mikrovállalkozások a kisvállalkozásokkal nagyjából egyenlö mértékü, az árbevétel $2 \%$-át valamelyest meghaladó mértékủ fejlesztési ráfordítást eszközöltek.

$\mathrm{Az}$ adatok nem annyira mondhatók hízelgőnek a kisebb méretú vállalkozásokra nézve, mint inkább elmarasztalóak a középvállalkozások tekintetében. A középvállalkozások 0,56\%-os adata rendkívül alacsonynak nevezhetö, és jól jelzi a leginkább életképes és versenyképes méretünek nevezhető dél-dunántúli középvállalkozói szféra jelentős finanszírozási problémáit.

A $\mathrm{K}+\mathrm{F}$ tevékenységet jellemző fontos mutató még a kutatás-fejlesztési tevékenységgel foglalkozó alkalmazottak száma. E tekintetben rendkívül elszomorító kép tárul elénk: a magát innovatívnak minősítő vállalkozások 94\%-a egyáltalán nem foglalkoztat $\mathrm{K}+\mathrm{F}$-re specializálódott munkatársat és alig 3\%-uk rendelkezik elkülönült $\mathrm{K}+\mathrm{F}$ részleggel. Ez összhangban van a korábbiakban említett, a Dél-Dunántúlra jellemző rendkívül kedvezőtlen $\mathrm{K}+\mathrm{F}$ statisztikai adatokkal.

\section{Az innováció-orientált fejlödés akadályai és szolgáltatási igényei}

Az innovációs tevékenységek erösítése és az erre irányuló támogatási politika hangsúlyainak kijelölése szempontjából alapvető fontosságú az innovatív fejlesztéseket gátló tényezők számbavétele. E tekintetben - nem meglepő módon - a déldunántúli KKV-k esetében első helyen áll a tökehiány, a vállalkozások közel fele említi a rendelkezésre álló szükös tőkeforrásokat az innovációs tevékenységek hátráltatójaként. A KKV-k negyede a rendelkezésre álló támogatások hiányára, míg ugyancsak negyedük a magas fejlesztési költségekre panaszkodik, melyek ugyancsak a finanszírozási források elégtelenségével összefüggő tényezőkként kezelhetök. Amennyiben e három tényezőt együttesen vizsgáljuk, elmondható, hogy a szükös financiális lehetöségek a vállalkozások $53 \%$-a esetében képezik az innovációs tevékenységek akadályát. Ez összhangban áll egy, még 1997-ben végzett országos innovációs felmérés tapasztalataival, miszerint Magyarországon hiányoznak az innováció finanszírozásához szükséges források, valamint az innovációs tevékenység fontos akadályát képezik a magas innovációs költségek (Döry 2001). Az innovációs politika első számú akcióterülete tehát egyértelmúen az innovációfinanszírozási lehetöségek javítása kell, hogy legyen. 
Márton György : Innovációs potenciál felmérés tanulságai egy elmaradott régióban.

Tér és Társadalom 18. évf. 2004/3. 127-149. p.

138 Versenyképesség

TÉT XVIII. évf. 2004

Az elavult technológiai színvonal is az innovációt jelentösen hátráltató tényezöként jelenik meg a KKV-k esetében. Ez is azt a következtetést erősíti meg, hogy a Dél-Dunántúlon müködő vállalkozások jelentős részénél a továbbfejlődés szempontjából megkerülhetetlen lépés a korszerütlen technológiai infrastruktúra modernizációja, söt sok esetben a teljes körü technológiai korszerüsítés. Amennyiben erre nem kerül sor, illuzórikus elvárás az innováció-orientált fejlödés, hiszen hiányoznak hozzá az alapvető háttérfeltételeket jelentö gépek és berendezések.

Az innovációt gátló faktorok közül megemlítendő még a kereslet hiány, ami a KKV-k ötödére jellemzö. Ez elöre vetíti annak igényét, hogy a KKV-k számára megfelelö marketing és piaci szolgáltatások álljanak rendelkezésre, melyek hozzájárulnak ahhoz, hogy a vállalkozások rátaláljanak az innovatív tevékenységek eredményeképpen létrejött termékek és szolgáltatások rentábilis termelését biztosító, fizetőképes keresletre. Ugyanez járulhat hozzá az innovációs tevékenységekkel óhatatlanul együtt járó jelentős kockázatok mérsékléséhez, mely ugyancsak fontos hátráltató (esetlegesen elrettentö) tényezőként jelenik meg.

Végezetül a szakismeret és a megfelelö partneri kapcsolatok hiánya mutatkozik még az innováció hátráltató tényezőinek. Az elöbbi esetében a regionális szakképzési rendszer modernizációja, a képzési kínálat piaci igényekhez történö közelítése, valamint a tanácsadási rendszer fejlesztése, míg utóbbi esetében - a fizetőképes kereslet biztosításához hasonlóan - a megfelelő piaci és marketing szolgáltatások elérhetősége járulhat hozzá a gátló tényezők csökkentéséhez (5. ábra).

\section{5. ÁBRA}

Az innováció hiányának okai

(Reasons for Lack of Innovation)

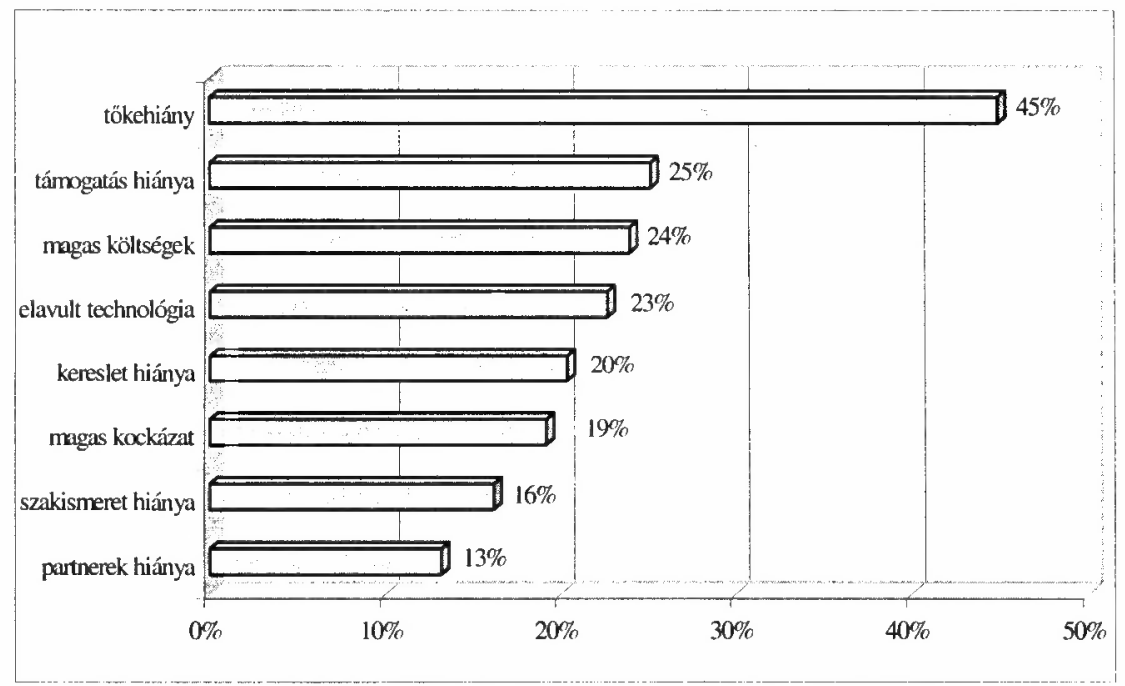

Forrás: Kérdőívek 2002. 
Márton György : Innovációs potenciál felmérés tanulságai egy elmaradott régióban.

Tér és Társadalom 18. évf. 2004/3. 127-149. p.

TÉT XVIII. évf. 2004 - 3

Versenyképesség

139

Az elözőekkel összefüggésben a felmérés kiterjedt a KKV-k által igényelt innovációs szolgáltatások feltérképezésére is. E tekintetben a pályázati szolgáltatások (pályázatkövetés, pályázatírás, pályázatok menedzsmentje) iránt mutatkozik a legnagyobb igény. Ez különösen az innovatív vállalkozások esetében van így, e vállalkozások mintegy $70 \%$-a igényel ilyen irányú külsö segítséget, ami igen magas arány! Ez jól rámutat arra, hogy a professzionális, az innovációs fejlesztéseket támogató hazai és európai uniós támogatási forrásokhoz történö hozzáférést a déldunántúli KKV-k saját kapacitásaikra támaszkodva túlnyomó részben nem látják kivitelezhetönek, többségük külső szervezet segítségét igényli ehhez. Amennyiben figyelembe vesszük, hogy mind az uniós és ezzel összefüggésben a hazai vállalkozás-fejlesztési politika is egyre nagyobb hangsúlyt helyez az innovációs tevékenységek támogatására, ennek megfelelően az ilyen jellegủ támogatási források jelentös bővülésére lehet számítani a közeljövöben, ez még inkább aláhúzza az innovációs pályázati tanácsadó rendszer fejlesztésének szükségességét a régióban. Jelentös igény mutatkozik a pénzügyi szolgáltatások iránt is. Ez összefüggésben van a pályázati szolgáltatási igénnyel, hiszen a pályázat-menedzsment fontos eleme a pályázatok végrehajtásával kapcsolatos pénzügyi folyamatok menedzsmentje.

A KKV-k mintegy harmada igényel külsö marketing szolgáltatásokat. Ez is összhangban áll az előzőekben ismertetett, az innovációt gátló tényezők közül a megfelelö fizetőképes kereslet hiányával. Marketing és piacra jutást segítő szolgáltatásokat azonban a vállalkozások bővebb köre igényel, ez is mutatja a marketing tevékenységek egyre növekvö jelentőségét a KKV-k sikeres múködésében.

Hasonló mértékủ a technológiai szolgáltatások iránti igény. Ez vonatkozhat a gyártás mennyiségének, minőségének vagy a gyártási rendszernek a fejlesztését elösegítỏ technológia-transzfer szolgáltatásokra.

Viszonylag kisebb igény mutatkozik az iparjogvédelmi szolgáltatások iránt, a KKV-k kevesebb mint 20\%-a igényel ez irányú külső asszisztenciát. Ez betudható annak, hogy az innovatív fejlesztések kisebb hányadát tervezik jogi oltalom alá vonni, egyrészt annak költség- és időigénye miatt, másrészt pedig abból kifolyólag, hogy az innovatív fejlesztések többségének egyszerüsége miatt nem racionális a jogi védelem alá helyezés (6. ábra).

A KKV-k által igényelt innovációs szolgáltatások kínálata szempontjából elsősorban a jelenleg a régióban múködő, a vállalkozások müködését segítő szervezetek jöhetnek számításba. A felmérés kitért arra, hogy a KKV-k milyen mértékben élnek e szervezetek szolgáltatásaival.

A legföbb tanulságként elmondható, hogy az elmúlt 3 évben innovatív fejlesztést megvalósitó cégek közel fele (43\%) egyáltalán nem vette igénybe az innovációs szolgáltatásokat nyújtó szervezetek szolgáltatásait. Ez rendkívül magas arány, ami jól mutatja azt, hogy jelentős hiányosságok mutatkoznak az innovációs intézményrendszer mủködésében és ezen intézmények vállalkozásokkal fenntartott kapcsolatait illetően. E számadat önmagában képes alátámasztani a regionális innovációs intézményrendszer fejlesztésének égetỏ igényét. 
Márton György : Innovációs potenciál felmérés tanulságai egy elmaradott régióban.

Tér és Társadalom 18. évf. 2004/3. 127-149. p.

\section{6. ÁBRA \\ Gazdasági szolgáltatások iránti igény \\ (Need for Business Services)}

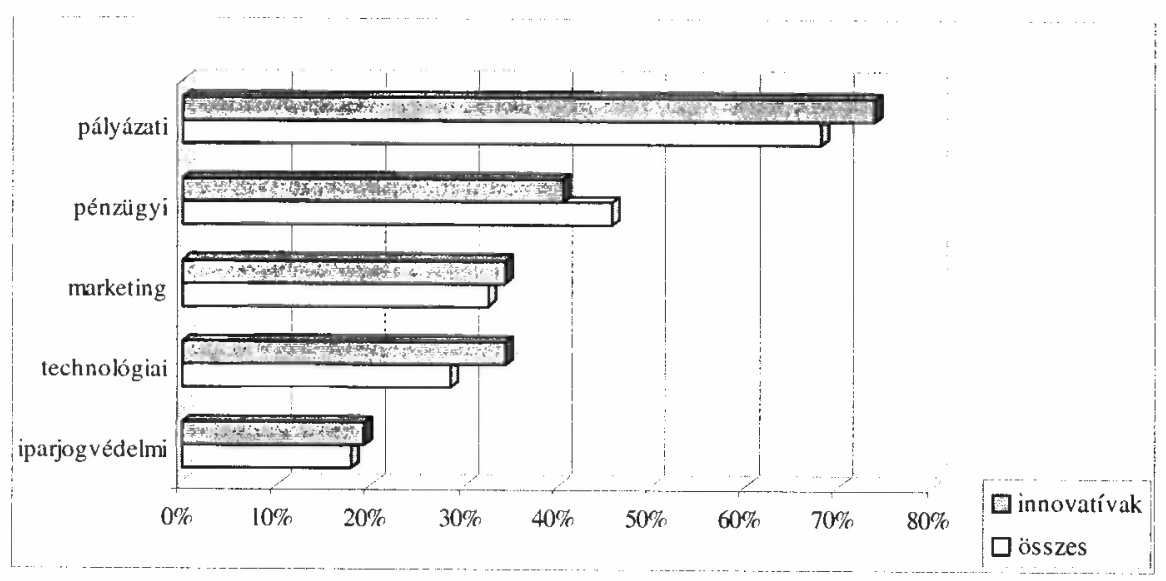

Forrás: Kérdöívek 2002.

A vállalkozások innovatív tevékenységét támogató szervezetek közül a vállalkozások leginkább a profitorientált tanácsadó cégekkel lépnek kapcsolatba (20\%). A részben vagy egészében közforrásokból finanszírozott intézmények egyike sem éri el ezt az arányt. Ez természetesen nem azt jelenti, hogy a tanácsadó cégekkel fennálló kapcsolatok mértéke magas (sőt, ez is alacsony arány), hanem sokkal inkább elmarasztaló a nonprofit szervezetekre nézve.

A nonprofit elven müködö szervezetek szolgáltatásait a $K K V-k$ alig több mint egynegyede (26\%) veszi igénybe. Jellemzö, hogy e vállalkozások fele egyszerre több szervezettől is igényel szolgáltatásokat innovációs tevékenységéhez. Ez jól mutatja a regionális innovációs intézményrendszer koordinálatlanságát, az egyes szervezetek között fennálló jelentős párhuzamosságokat. A szétaprózott, átfedéseket magában hordozó müködés a fejlettebb régiók innovációs intézményrendszerét is jellemzi, így ez tapasztalható pl. a Közép-Dunántúlon is (Grosz-Csizmadia-Szépvölgyi 2004). Elmondható tehát, hogy a regionális innovációs intézményrendszer koordinált müködésének elósegítése országos szintü feladat. A jelenlegi kormányzati szándékok szerint ezen intézményrendszer fejlesztésére 2004-ben kormányzati támogatási források is rendelkezésre állnak. A hatékony intézményi modell kialakítását azonban az egyes régiók problémáira és igényeire szabottan, regionális szinten kell megtenni.

A nonprofit elven müködő szervezetek közül a felsőoktatási intézmények bírnak a leginkább aktív vállalkozói kapcsolatokkal, azonban így is mindössze minden hatodik KKV rendelkezik egyetemi kapcsolatokkal. A vállalkozásokat segítỏ szervezetek (kamarák, helyi vállalkozói központok) ennél is alacsonyabb arányt tudnak felmutatni (13\%). A kutatóintézetekkel létesített kapcsolatok elenyészőek. A régióban mindössze három kutatóintézet múködik, s ezeknek a helyi KKV-kkal fenntartott kapcsolatai igen gyengék (7. ábra). 
Márton György : Innovációs potenciál felmérés tanulságai egy elmaradott régióban.

Tér és Társadalom 18. évf. 2004/3. 127-149. p.

TÉT XVIII. évf. 2004 3 Versenyképesség

\section{7. ÁBRA}

$A$ vállalkozások innovációs partnerei

(Main Partners of SMEs in Innovation)

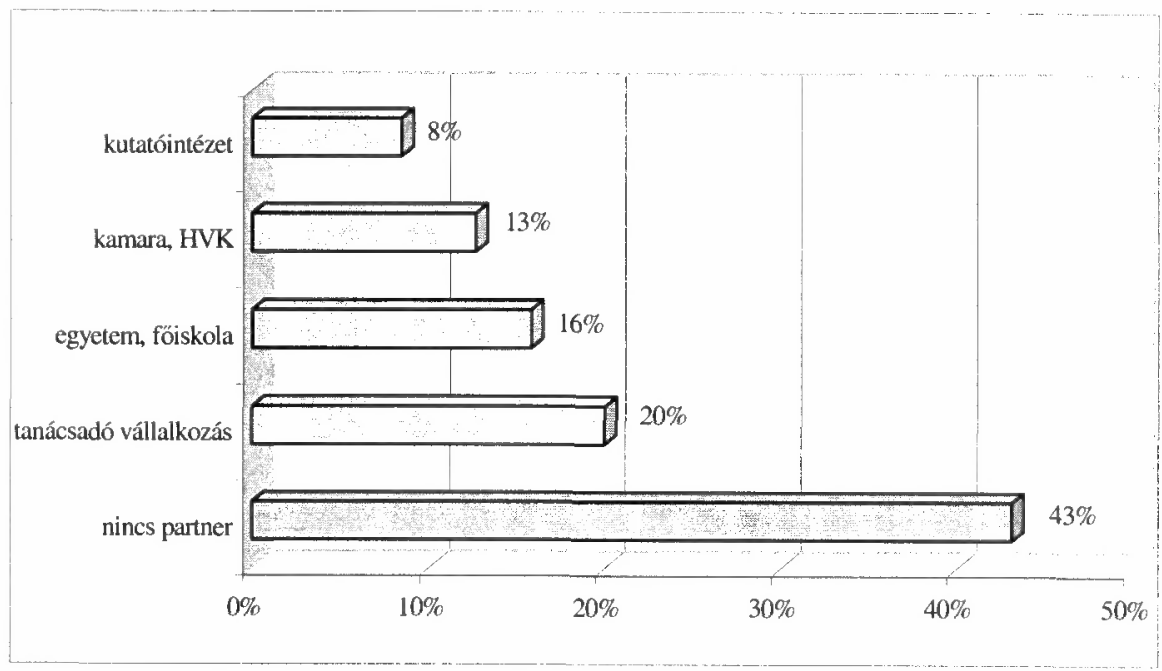

Forrás: Kérdőívek 2002.

\section{Az innováció külső finanszírozási igénye}

Mint azt az előzőekben láthattuk, az innovációs tevékenységek erősítése szempontjából elsörendủ feladat az adekvát innováció-finanszírozási formák kialakítása és hatékony alkalmazása. Ezért a felmérés részletesen vizsgálta a vállalkozások számára jelenleg vagy a jövőben potenciálisan elérhetö külső finanszírozási lehetöségeket, valamint az ezekkel szembeni elvárásokat. Az elemzés számos fontos következtetés levonását teszi lehetővé egy hatékony regionális innováció-finanszírozási modell kialakításához.

A felmérés során az összes fö külső finanszírozási forma vizsgálat alá került az innovációs tevékenységek finanszírozása szempontjából. Ennek megfelelỏen a külső hitelfelvétel, a hitelgarancia támogatás, a közpénzböl folyósított támogatás, valamint a kockázati töke bevonásának lehetösége egyaránt a vizsgálat tárgyát képezte.

A négy külső finanszírozási forma közül egyértelmủen a hitelfinanszírozás iránt mutatkozik a legnagyobb igény (8. ábra). Az innovatív vállalkozások minden egyes finanszírozási konstrukció esetében az átlagosnál nagyobb igényt mutatnak fel. Ez jól jelzi az innovációs tevékenységek jelentős forrásigényét, egyúttal tovább nyomatékosítja a specifikus innováció-finanszírozási eszközök kialakításának és alkalmazásának szükségszerüségét. 
Márton György : Innovációs potenciál felmérés tanulságai egy elmaradott régióban.

Tér és Társadalom 18. évf. 2004/3. 127-149. p.

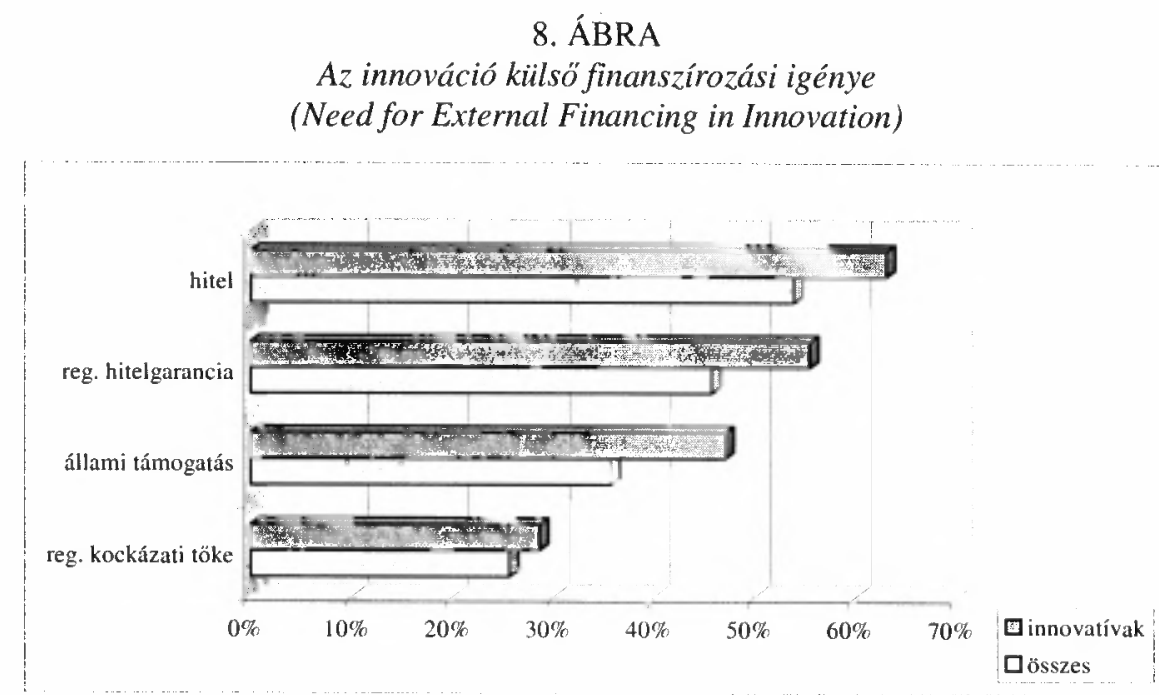

Forrás; Kérdőívek 2002.

\section{Hitelfinanszírozás}

Érdekes következtetések vonhatók le, ha az innovatív fejlesztések finanszírozására fordított hitelek jellemzőit vizsgáljuk. Elmondható, hogy mind a felvett hitelöszszeg, mind pedig a lejárati idó tekintetében az átlagosnál nagyobb értékek jellemzik az innovációs tevékenységek külső hitelfinanszírozását.

\section{9. ÁBRA}

Az igényelt hitelek összeg szerinti megoszlása (millió Ft/hitelfelvétel) (Breakdown of Credits by Amounts [million HUF / credit contract])

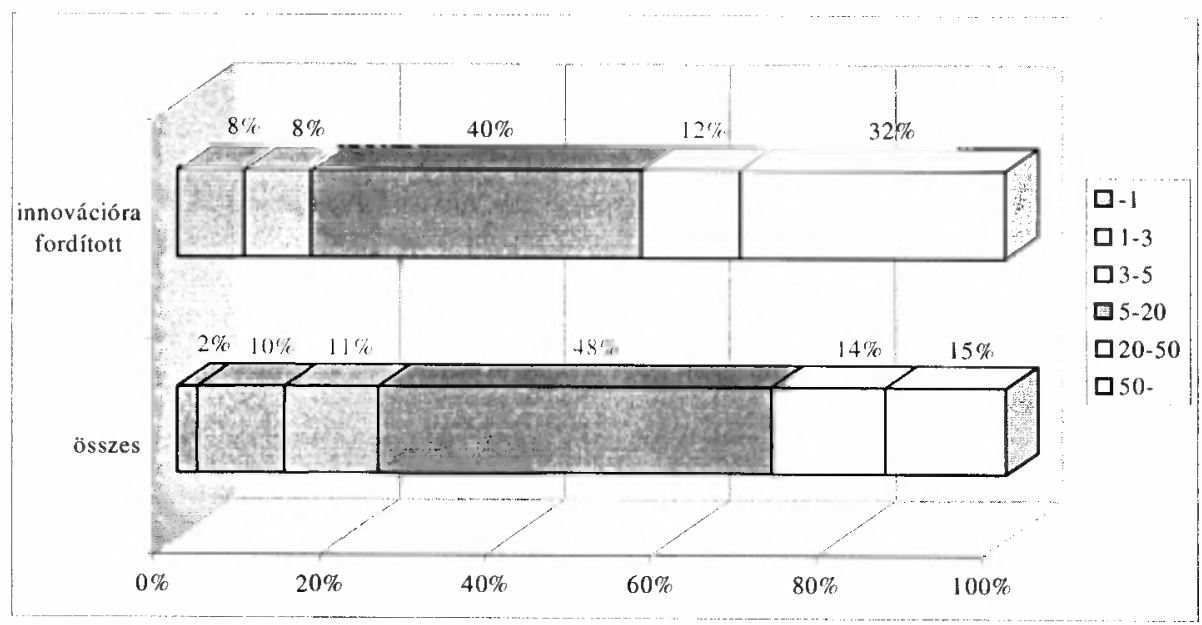

Forrás: Kérdőívek 2002. 
A felvett hitelek összege zömmel az 5-20 millió Ft-os sávba esik. Szembetünő azonban, hogy a döntöen az innovációs tevékenységek finanszírozását szolgáló hitelek esetében az átlagosnál jóval nagyobb a jelentősebb összegủ hitelek aránya (míg az innovációra fordított hitelek 43\%-a 20 millió Ft-ot meghaladó összegủ, az összes hitelfelvétel esetében ez az arány csupán 29\%). Különösen magas a nagy összegü (50 millió Ft-ot meghaladó) hitelaktusok aránya az innováció-finanszírozás esetében, a felvett hitelek közel egynegyede tartozik e körbe (9. ábra). Az innováció-finanszírozás esetében tehát a hitelintézeteknek azonos jelentóséget kell tulajdonítaniuk a közepes és a nagy összegü hitelek folyósításának.

A folyósított hitelek futamideje tekintetében is jelentős eltérések állapíthatók meg az innovációs célú hitelek esetében. A KKV-k által igénybe vett hitelek között nagyjából azonos gyakorisággal szerepèlnek az éven belüli, a középtávú (max. 3 éves) és a hosszabb lejáratú (elsősorban a 3-5 éves futamidejü) hitelek. Az innovációs fejlesztésekre fordított hitelek esetében szinte elenyésző az éven belüli hitelfelvétel, ezzel szemben döntỏ szerepet játszanak a hosszabb lejáratú hitelkonstrukciók (föként a 3-5 éves lejáratok dominálnak). A felvett hitelek több mint fele (54\%) 3 éven túli lejáratú (10. ábra).

\section{0. ÁBRA}

Az igényelt hitelek futamidö szerinti megoszlása (év)

(Breakdown of Credits by Maturity [years])

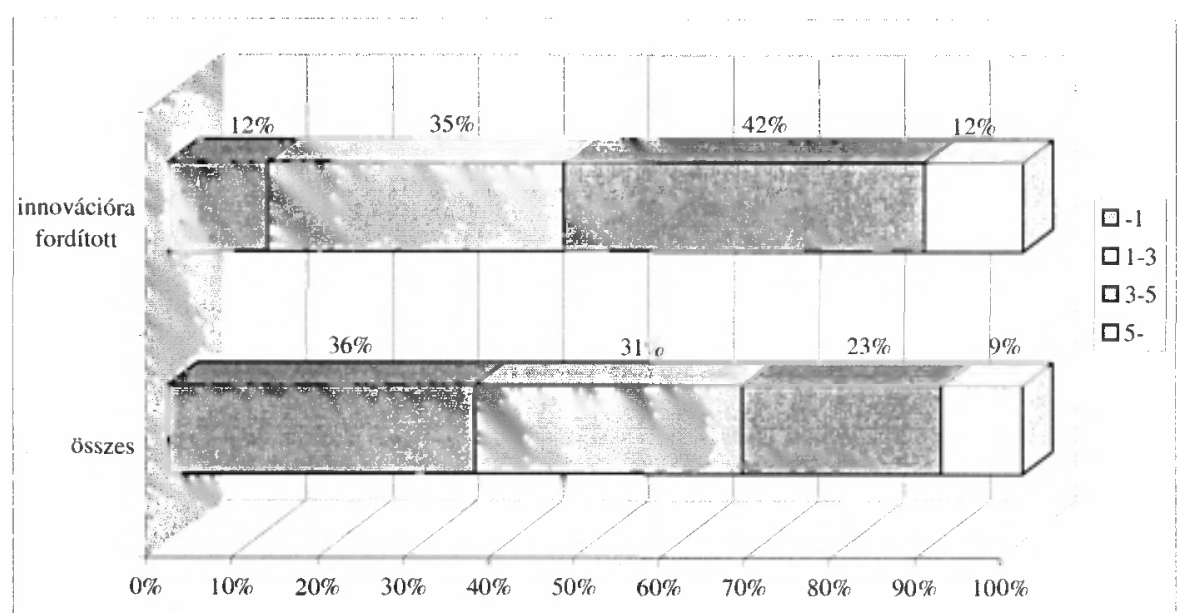

Forrás: Kérdöívek 2002.

Tanulságos információkkal szolgál a hitelkonstrukciókkal kapcsolatos föbb problémák számbavétele. A hitelfelvételt gátló tényezők sorában első helyen áll a hitelintézetek alacsony kockázatvállalási készsége. E problémakör súlyát tovább növeli, hogy a fontosabb problémák sorában ezt az alábbiak követik:

- biztosíték elvárások magas szintje;

- adminisztratív terhek;

- költségterhek. 
E problémák mindegyike közös töröl gyökerezik: a KKV-k többsége a hitelintézetek túlzott óvatosságáról és kinnlevöségeik túlbiztosításáról panaszkodik. E jellemzök sajnos ellentétben állnak az innovatív tevékenységek finanszírozási követelményeivel. Az új termékek, technológiák kifejlesztésével és bevezetésével óhatatlanul együtt jár a jelentösebb kockázat, ráadásul épp e tevékenységek szorulnak rá a nagyobb összegủ és futamidejü külső finanszírozásra.

Megállapítható tehát, hogy az innovációs tevékenységek finanszírozásához a jelenleg megszokottaktól eltérö hitelkonstrukciók alkalmazására van szükség. Ezek közös jellemzöje a nagyobb hitelösszeg és a hosszabb futamidö. Tekintettel arra, hogy e kondíciók a KKV-k számára az átlagosnál jóval magasabb terhet és ebböl fakadóan a hitelezö számára nagyobb kockázatot jelentenek, indokolt, hogy a hitelintézetek speciális hitelkonstrukciók kidolgozásával tegyék lehetővé az innovációk finanszírozását. A kockázatok mérséklése, valamint a KKV-k számára kedvezöbb hitelkondíciók elérése érdekében e tekintetben szóba jöhetnek az állam, illetve a régiók által támogatott, a KKV-k innovatív fejlesztését segítő hitelek.

\section{Hitelgarancia}

A hitelek elérhetősége szempontjából nagy jelentösége van a biztosíték elvárások teljesítésének. Ez köztudomásúlag sok esetben hatalmas terhet ró a KKV-kra, számos esetben lehetetlenné téve a hitelfelvételt. A felmérés szerint a KKV-k által felvett hitelek döntö része jelzáloggal, ezen belül is túlnyomórészt ingatlan biztosítékkal fedezett. Ehhez képest a KKV-k jóval kisebb arányban veszik igénybe a hitelgaranciát, elsősorban természetesen annak jelentős költségigénye miatt. A felmérés kimutatta, hogy míg a KKV-k csupán $18 \%$-a veszi igénybe a jelenleg müködö, állam által támogatott hitelgarancia alapok szolgáltatásait, addig több mint kétharmaduk (68\%) venné igénybe egy regionális garanciaszervezet szolgáltatásait. Bár e számok csupán orientáló jellegüek, arra azonban alkalmasak, hogy felhívják a figyelmet a támogatott garancia konstrukciók jelentőségére és az ez irányú szolgáltatások bővítésének lehetöségére.

A felmérés eredményei alapján a regionális hitelgarancia iránt érdeklődő KKV-k elsősorban 25-49\%-os mértékủ garanciavállalás iránt érdeklödnek, de számos KKV ennél magasabb arányú garancia igénybevételét is elképzelhetőnek tartja. Az innováció-finanszírozás fontos területe lehet tehát az innovációs célból felvett hitelek garantálása, regionális hitelgarancia konstrukciók kidolgozása és bevezetése.

\section{Közpénzböl folyósított támogatások}

A külső finanszírozás szempontjából a hitelfelvétel mellett a fejlesztési tevékenységek esetében nagy szerepe van a közpénzböl folyósított támogatásoknak, ezen belül is elsősorban a vissza nem térítendő támogatási lehetőségeknek.

A közpénzböl folyósított támogatások innováció-finanszírozásban betöltött jelentôs szerepét mutatja, hogy a támogatásban részesült innovatív cégek a felvett 
támogatások több mint felét (52\%) döntően az innovatúv tevékenység finanszírozására használják fel, míg ugyanez az arány a hitelfelvételek esetében csak $36 \%$. Látható tehát, hogy a közpénzböl folyósított támogatások valódi rásegítö szerepet játszanak a költségigényes innovativ fejlesztések esetében, $\mathrm{s}$ fontos szerepet töltenek be a rendelkezésre álló hitelkonstrukciók által kínált finanszírozási lehetőségek kiegészítésében.

Bár nem olyan szembetủnő módon, de az innovációs céllal igénybe vett támogatások jellege is mutat némi eltérést az átlagoshoz képest. Ez esetben is megállapítható, hogy az innovatív tevékenységek finanszírozási igénye az átlagosnál nagyobb. Ez föként a kis összegü ( 1 millió $\mathrm{Ft}$ alatti) támogatások alacsonyabb arányában, valamint az 5 millió Ft-ot meghaladó összegủ támogatások nagyobb gyakoriságában tükrözödik. Az innovációs célú támogatási konstrukciók szempontjából elsösorban az 1-3 millió Ft, valamint az 5-20 millió Ft közötti támogatásoknak lehet nagyobb szerepük (11. ábra).

\section{1. ÁBRA}

Az igényelt támogatások összeg szerinti megoszlása (millió Ft)

(Breakdown of Grants by Amounts [million HUF])

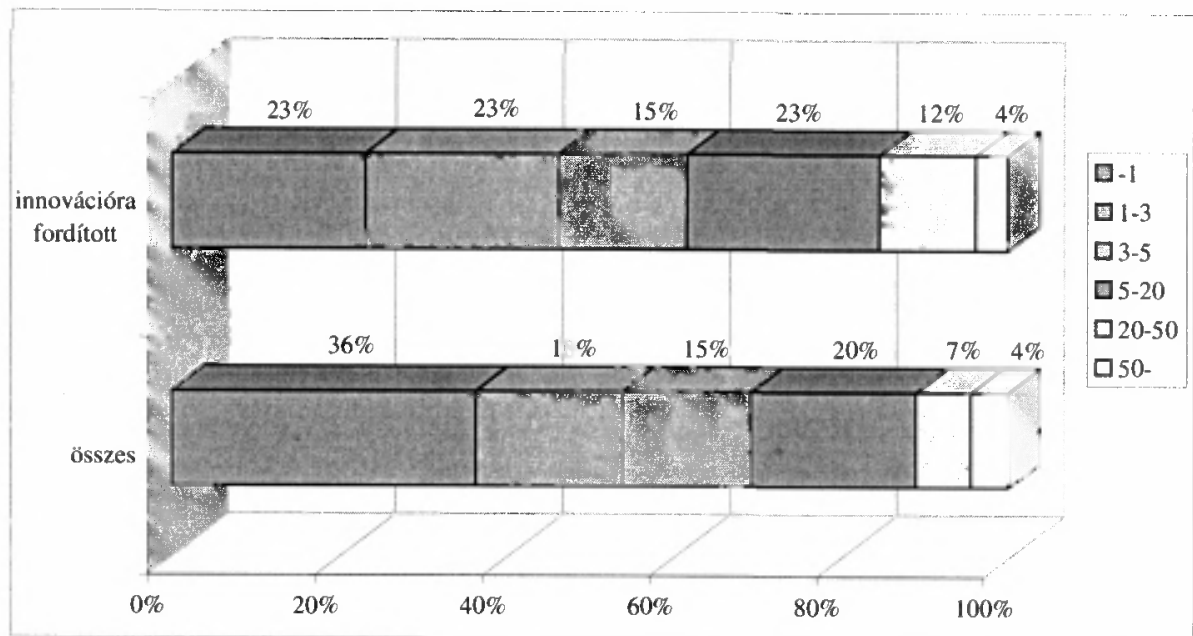

Forrás: Kérdőívek 2002.

\section{Kockázati töke}

A felmérés foglalkozott egy, eleddig a dél-dunántúli KKV-k számára ismeretlen finanszírozási forma, a kockázati tőke alkalmazásának lehetőségével is. A szakirodalom a kockázati tőkefinanszírozási tevékenység definíciójaként az alábbi meghatározást adja: ,,a kockázati tőke hivatásos pénzügyi közvetítők alaptőke-befektetését jelenti olyan, tỏzsdén nem jegyzett vállalkozásokba, amelyek az átlagosnál nagyobb növekedési potenciállal, illetve értéknövelő képességgel rendelkeznek, és ahol a befektetők célja a maximális tökenyereség" (Karsai 1995, 19). A kockázati tőke jelentỏsége abban van, hogy a hagyományos hitel-típusú finanszírozás helyett 
tőke-típusú finanszírozást valósít meg. Az ilyen tevékenységet végzö befektető cégek gazdasági szemlélete eltér a kereskedelmi bankokétól, és ebből az eltérő megközelítésböl fakadóan olyan KKV-k fejlesztését is finanszírozzák, amelyek azt hitelből, saját forrásból, vagy egyéb idegen források bevonásával nem tudnák megoldani (Célegyenesben a kockázati tőke 1998). Ebből következően az innovatív, az új termékek és technológiák bevezetésére és elterjesztésére alkalmas KKV-k potenciális célpontjai a kockázati tökebefektetéseknek.

A felmérésbe bevont $K K V$-k egynegyede tartja reálisnak kockázati töke igénybevételét a vállalkozása tỏkeellátottságának javítása érdekében. Figyelemre méltó, hogy a kockázati tőke iránti érdeklödés szempontjából nincs jelentős különbség az egyes vállalkozási méretkategóriák között. Ugyan a mikrovállalkozások csak kisebb hányada tartja elképzelhetőnek ezen újszerü finanszírozási formát, a kis-és közepes vállalkozások nagyjából hasonló arányban mutatnak érdeklödést a kockázati töke iránt. A kockázati tőkebefektetés tehát már a kisvállalkozások esetében is reális tőkepótló eszköznek bizonyulhat.

A kockázati tőke paramétereit vizsgálva, a felmérés adatai azt mutatják, hogy az igényelt befektetési összeg átlagos nagysága megközelíti a 40 millió Ft-ot. E tekintetben sincs releváns különbség a kis- és a közepes méretü vállalkozások között (12. ábra). A KKV-k többsége 10-50 millió Ft közötti tökebefektetési összegben gondolkodik.

\section{2. ÁBRA}

A kockázati tökebefektetés reálisnak tartott összege (millió Ft)

(Required Amount of Venture Capital Investment [million HUF])

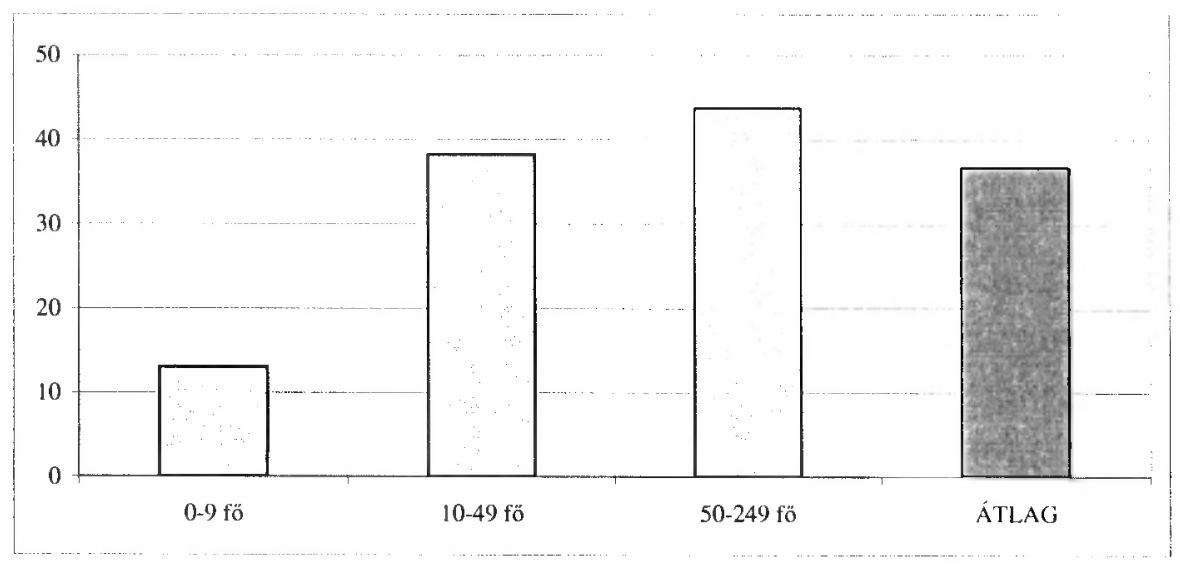

Forrás: Kérdőívek 2002.

A kockázati tökebefektetés igénybevétele szempontjából fontos paraméter a kockázati tökerészesedés elvárt mértéke. A KKV-k 84\%-a kisebbségi részesedést tart elképzelhetönek. Érdemes ezt az értéket összehasonlítani egy korábbi nemzetközi felmérés eredményeivel, mely szerint a nyugat-európai KKV-kban tulajdonrészt szerzett kockázati tőkések $61 \%$-a rendelkezik kisebbségi részesedéssel 
Márton György : Innovációs potenciál felmérés tanulságai egy elmaradott régióban. Tér és Társadalom 18. évf. 2004/3. 127-149. p.

(The Economic Impact... 1996). A Dél-dunántúli régióban müködő KKV-k tehát csak szerényebb mértékben látják elképzelhetönek idegen tőke tulajdonszerzését. Ez nem meglepő, hisz a dél-dunántúli vállalkozások számára ismeretlen a kockázati tőkebefektetés, ráadásul a magyar KKV szektor egészére jellemző bizonyos fokú idegenkedés a külsổ tőkebefektetéstôl.

A reálisnak tartott futamidő tekintetében az innovációs célú hitelfinanszírozást is meghaladó, nagyobb futamidejü tókebefektetésekben gondolkodnak a vállalkozások (közel háromnegyedük 3 éven túli futamidejü befektetést igényelne). Ez megfelel a realitásoknak, hisz tőkebefektetésről lévén szó, a pénz forgási sebessége is kisebb, a tökerészesedés értékesítésére csak hosszabb távon, megfelelö kilépési (exit) lehetöségek esetében kerülhet sor.

Végezetül tanulságos megvizsgálni, hogy a KKV-k mely tulajdonságokat tartják relevánsnak a kockázati tőkebefektetéssel szemben. A legfontosabb tulajdonságként a hosszú távú gondolkodás került megnevezésre, de a vállalkozások jelentős szerepet tulajdonítanak a tỏkebefektetỏ innovatív hajlandóságának is. Bár fontos szempontként került megemlítésre, de a hosszú távú gondolkodáshoz képest kisebb nyomatékot kap a nyereség centrikusság. Levonható tehát az a következtetés, hogy a KKV-k reálisnak tartják a kockázati tỏkebefektetést az innovatív fejlesztéseik finanszírozása szempontjából, de jellemzöen stabil, megbízható tökéstársban gondolkodnak, aki a hosszú távú siker érdekében képes háttérbe szorítani a rövid távú profitszerzési szándékait.

A jelenleg Magyarországon működő, alapvetően külföldi tulajdonú kockázati tőkealapok minimálisan egy nagyságrenddel nagyobb tökebefektetésekben érdekeltek, így éppen az a tókebefektetói réteg hiányzik, amely reálisan elérhetö lenne a déldunántúli innovatív $K K V$ - $k$ számára. A fentieket figyelembe véve reális lehetöség van egy dél-dunántúli regionális kockázati tökealap létrehozására, ami regionális támogatással jönne létre, és elsősorban a régióbeli innovatív fejlesztési akciók finanszírozását lenne hivatott elősegíteni. A tỏkealap finanszírozási szabályrendszerének kialakításakor figyelembe kell venni a dél-dunántúli KKV-k speciális finanszírozási igényeit, mind az igényelt tőkeösszeg, mind a futamidő, mind pedig az üzletpolitika és hozamelvárás tekintetében. A kívánt pozitív hatások elérése érdekében egy ilyen regionális kockázati tőkealap müködése során összhangba kell hozni a területfejlesztési célkitüzéseket a nyereségérdekeltségi szemlélettel. Általánosságban elmondható, hogy egyik érdekrendszer sem érvényesüllhet a másik rovására, hiszen hosszú távon csak profitábilis KKV-kba történő befektetések szolgálhatják a regionális fejlesztési célok teljesülését (Márton 2001).

\section{Összegzés}

Az innovációs potenciál felmérés célcsoportját szándékoltan a Dél-dunántúli régió „tradicionálisnak" nevezhető ipari és építőipari ágazataiban tevékenykedő, elsősorban hazai tulajdonú KKV-k képezték. A vizsgálat fö célja, hogy rámutasson arra, az inno- 
vációs aktivitás jelentös szerepet játszhat egy hátrảnyos helyzetü régió hagyományos iparágaiban müködö KKV-k piaci pozicióinak és versenyképességének javitásában.

$\mathrm{Az}$ innovatív hajlam, az új termékek és technológiák bevezetésének képessége szoros összefüggésben van a vállalkozások jövedelemtermelő képességével, azok sikerességével. Különösen a nyereségességi és hatékonysági mutatók tekintetében élveznek jelentös elönyt az innovatív vállalkozások, de az exportképesség is korrelációt mutat az innovációs tevékenységek jelenlétével.

Az innovativitás több tényezövel is magyarázható. Így különbségek mutathatók ki az egyes ágazatok és az egyes tevékenységi formák innovatív jellege között, de a külföldi tőke jelenléte és a vállalkozások humán kapacitásának minösége is jelentősen befolyásolja az innovációs képességet.

Az innovációt akadályozó tényezők közül - nem meglepő módon - messze kiemelkedik a forráshiány, ami szoros összefüggésben van a külső finanszírozási lehetöségek korlátaival. Nagy igény mutatkozik az innovációs tevékenységek jellegzetességeit figyelembe vevő, testre szabott innováció-finanszírozási rendszer kialakítására.

További jelentős problémaként jelentkezik a vállalkozás-támogató intézményrendszer szétforgácsoltsága, az általuk kínált szolgáltatások iránti csekély érdeklödés. Szükség van egy komplex, regionális szinten koordinált, innovációt támogató intézményrendszer kialakítására is. Ez alapvetően a már müködö intézmények bázisán jöhet létre, azonban nagyon fontos a rendszer szereplöi közötti folyamatos információáramlás és az ésszerü munkamegosztás.

A Magyar Kormány döntött a hazai innovációs rendszer megreformálásáról, ezzel összefüggésben, 2004-ben létrehozta a Kutatási és Technológiai Innovációs Alapot. Ezzel párhuzamosan a Dél-Dunántúlon kidolgozásra kerïlt a Regionális Innovációs Stratégia (RIS), amely középtávon meghatározza az innovatív fejlesztések fő célterületeit és prioritásait. E rendszerszintü változások remélhetőleg érdemben képesek majd hozzájárulni ahhoz, hogy végre a Dél-Dunántúlon is teret nyerjen az innovációs kultúra, a régióban müködő KKV-k felismerjék az innovációs fejlesztésekben rejlö lehetőségeket. A régió gazdasági felzárkózása ugyanis elképzelhetetlen az itt müködö KKV-k versenyképességének erősödése nélkül, melynek kulcseleme éppen az innováció, a vállalkozások megújulási képessége.

\section{Jegyzet}

${ }^{1}$ A tanulmány alapjául szolgáló kérdöíves felmérés a Dél-Dunántúli Regionális Fejlesztési Ügynökség Kht., az Innovációs és Technológia-fejlesztési Központ Kht. és a Kapos Innovációs Transzfer Központ Kht. közötti együttmüködés keretében került lebonyolításra. 


\section{Irodalom}

Célegyenesben a kockázati töke. (1998) - Magyar Hírlap. Január 10. 7. o.

Döry T. (2000) Vállalkozások innovációs tevékenysége a Közép-Dunántúlon. - Tér és Társadalom. 2-3. 53-62. o.

Döry T. (2001) Az innováció kutatások megjelenése a regionális elemzésekben - az innováció regionális perspektívában. - Tér és Társadalom. 2. 87-106. o.

European Innovation Scoreboard. (2003) European Commission, Brussels.

Farkas B.-Lengyel I. (2001) Regionális versenyképesség és kohézió az Európai Unióban. - Tér és Társadalom. 3-4. 231-252. o.

Green Paper on Innovation. (1995) European Commission, Brussels.

Grosz A.-Csizmadia Z.-Szépvölgyi Á. (2004) A regionális innovációs rendszer kínálati oldala a KözépDunántúlon. - Tér és Társadalom. 3. 111-125. o.

Horváth Gy. (1998) Európai regionális politika. Dialóg Campus, Budapest-Pécs.

Karsai J. (1995) A kockázatitőke-finanszírozás nyiltt és rejtett csatornái Magyarországon. - Külgazdaság. 10. 19.0.

Márton Gy. (2001) A kockázati tỏke lehetöségei a kis- és középvállalkozások finanszírozásában a Déldunántúli régió szemszögéböl. - Andrássy Gy.-Cseresnyés F. (szerk.) Magyarország és Európa az ezredfordulón. PTE Európa Központ, Pécs. 147-159. o.

A new partnership for cohesion - Third report on economic and social cohesion. (2004) Office for Official Publications of the European Communities, Luxembourg.

Raffay Z.-Gál Z. (1999) Regionális innovációs központok létrehozása Magyarországon. MTA RKK DTI, Pécs.

Területi Statisztikai Évkönyvek. KSH, Budapest.

The Economic Impact of Venture Capital in Europe. (1996) Coopers\&Lybrand Corporate Finance EVCA, Paris-Zaventem. 